\title{
Episodic Biogeochemical Variability in a Low-Flow Mediterranean Estuary
}

\author{
Gotzon Basterretxea ${ }^{1}$ (D) Antoni Jordi ${ }^{1}$ - Marly Carolina Martínez-Soto ${ }^{1}$. \\ Antonio Tovar-Sánchez ${ }^{1,2}$
}

Received: 14 March 2016 / Revised: 9 January 2017 / Accepted: 10 January 2017 / Published online: 23 January 2017

(C) Coastal and Estuarine Research Federation 2017

\begin{abstract}
To investigate to what extent episodic physical processes regulate nutrient availability and phytoplankton assemblages of the Mahon estuary (Minorca Island), we carried out an intensive field study during 2010-2011. During the study period, environmental conditions spanned from intense stratification to a continuous mixing and from lack of riverine inflow to intense runoff. Our data reveals a sequence of biogeochemical states of the estuary that result from the interplay between runoff, other non-periodic forcings (winds, sea level oscillations), and variations in water renewal. Seasonal runoff was revealed as a major driver of winter circulation and of the influx of inorganic nutrients, in particular nitrate. However, because of the combination between runoff and flushing time, the effects of floodwater events on phytoplankton are shortlived (days). Conversely, during summer, when freshwater influx declines, water renewal relies on pulsed atmospheric forcing that may be of local or remote origin. As depicted from the low nitrate concentrations $(<1 \mu \mathrm{M})$ and enhanced ammonium $(>1 \mu \mathrm{M})$, this change in circulation and external loads carries nutrient assimilation within the estuary head and forces the use of remnant nutrients through regenerating pathways to
\end{abstract}

Communicated by Dennis Swaney

Electronic supplementary material The online version of this article (doi:10.1007/s12237-017-0212-7) contains supplementary material, which is available to authorized users.

Gotzon Basterretxea

gotzon@imedea.uib-csic.es

1 Institut Mediterrani d'Estudis Avançats, IMEDEA (UIB-CSIC), Miquel Marqués 21, 07190 Esporles, Illes Balears, Spain

2 Department of Ecotoxicology, Ecophysiology and Biodiversity of Aquatic Systems, ICMAN (CSIC), Campus Universitario Río San Pedro, 11510 Puerto Real, Cádiz, Spain sustain an enhanced phytoplankton biomass at the lower estuary. Episodic variability represented between 52 and $65 \%$ of the annual chlorophyll variance. Despite the fact that episodic pulses represented intense departures from base biogeochemical state of the estuary, at time scale larger than weeks, the phytoplankton community composition and dynamics was largely regulated by the integrated effect of these episodes and other environmental drivers associated with seasonality rather than by individual storm events only. Our results suggest that even though the system presents good recovery capacity to individual storm episodes, it may be more vulnerable to increased nutrient fluxes during summer, as well as to changes in episode timing and frequency.

Keywords Nutrients $\cdot$ Phytoplankton $\cdot$ Variability · Episodes $\cdot$ Estuary $\cdot$ Mediterranean Sea

\section{Introduction}

Ecological variability patterns in coastal systems are typically characterized by responses to periodical physical and chemical forcing, induced by both low-frequency periodic forcings (e.g., seasonality) and tides and by other short-term oscillations (e.g., wind mixing, solar irradiance; e.g., Blauw et al. 2012). Superimposed on these periodic variations are other aperiodic or episodic disturbances which are generally mediated by changes in the atmospheric forcing (e.g., Chen et al. 2010). The effects of this shorter-term variability are often considered as "noise" blurring the relevant ecological patterns. In some coastal areas, however, particularly in those with small tidal range, the event-scale physical variability can be a major regulator of the biogeochemical fluxes, inducing profound impact on the structure and functioning of their respective coastal ecosystems (e.g., Gillanders and Kingsford 2002). 
Many regions of the Mediterranean coasts present this duality between seasonal and weather-driven ecological variations (e.g., Arin et al. 2013; Romero et al. 2014). In open waters, seasonality is characterized by a strong contrast between the stratified oligotrophic conditions occurring in summer and the more productive winter mixed conditions (Siokou-Frangou et al. 2010). Conversely, fueled by the high nutrient availability from anthropogenic sources, in nearshore waters, maximum production often occurs in summer (e.g., Garcés and Camp 2012). In the absence of significant tides, coastal circulation in the Mediterranean is highly conditioned by changes in wind forcing, and thus, coastal water renewal responds to these variations (e.g., Jordi et al. 2011). In these waters, the canonical seasonal pattern can be markedly disturbed by episodic variability of meteorological origin, manifested as sudden and intense wind pulses and/or intense rain episodes lasting for few hours to days interrupting the overall calm conditions. Sea level variations and runoff are also major regulators of coastal-ocean exchanges. Most notably, irregularity and often very stormy precipitation patterns result in null or small base freshwater flow during long periods that are disrupted by pulses of flash floods transporting sediments, nutrients, organic matter, and other compounds from a watershed to the coast. During these events, freshwater discharge to the coast can be multiplied by a factor of 10 (Estrela et al. 2001), delivering a significant proportion of the annual loads of inorganic and organic compounds to the coastal zone. The biogeochemical changes associated with these episodic stress events provoke departures from equilibrium states that differ depending on a number of biotic and abiotic factors (geomorphology, ecosystem structure, etc.), giving rise to a variety of ecosystem responses.

Due to their confined nature, and the integrative effects they exert over the input from extensive regions, estuaries, bays, and other semi-enclosed coastal areas are particularly responsive to episodic events affecting their terrestrial and oceanic boundaries and present marked fluctuations in their environmental conditions (Cloern 1991; Harding 1994; Paerl 1997). Estuaries, and other transitional environments, provide habitat for diverse marine communities and natural resources of economic and social importance and have a functional role as ecotones intervening in the decomposition of organic matter and nutrient cycling (Levin et al. 2001). Ephemeral river discharges, together with strong evaporation and weak tidal mixing, result in complex estuarine flow patterns under the Mediterranean climate, including quasi-neutral (stagnant) flow conditions and water circulation reversals (Hearn 1998; Largier et al. 1997). These flow variations strongly determine the exchange with the ocean, thereby affecting water properties. Moreover, connections between benthic and pelagic environments may be either reinforced during enhanced energy periods, by increasing material processing and nutrient cycling, or uncoupled under low forcing situations (e.g.,
Ubertini et al. 2012). These variations have consequences in the biogeochemical role of estuarine systems in response to the changing forcings. For example, they can act as preferential conduits of organic matter and nutrients that subsidize the adjacent coastal areas, as biochemical filters that retain certain elements, or as self-contained systems uncoupled from the coastal ocean. Nutrient availability can also cause shifts in function through changes to primary production that transfer through the food change to modify the ecosystem structure (Borum and Sand-Jensen 1996; Nielsen and Richardson 1996). Phytoplankton response to nutrient enrichment not only depends on the load but also on the stoichiometric ratios, timing, rate and pattern of delivery (e.g., Howarth 1988).

The increasing anthrophized nature of the coastal areas, and the consequent modification of the biology and chemistry of the seawater and sediments that it involves, may have altered the resilience of coastal systems to environmental variability. This has noticeable consequences in the biogeochemical cycling of nutrients and in the role of coastal areas as buffer zones between terrestrial and marine systems. Although it is a global issue, anthropogenically enhanced delivery of nutrients and other elements to the coast may be particularly critical in Mediterranean oligotrophic areas, where inputs from terrestrial systems account for a larger fraction of the coastal budgets, and where even small disturbances can produce notable effects. However, while the importance of episodic disturbances in the regulation of ecosystem biogeochemistry has been demonstrated in areas of major exchanges, such as large rivers and estuary areas in humid climates (Yeager et al. 2005; Gobler et al. 2005; Rudek et al. 1991), their effects on the Mediterranean coastal systems have been given less consideration (e.g., Lipizer et al. 2012; Nicolau et al. 2006; Spatharis et al. 2007).

Semi-enclosed water bodies fed by small fluvial drainage basin environments are common systems in low tidal range, semi-arid Mediterranean regions (Lichter et al. 2011). Most of the studies carried out to date in the Mediterranean are centered on the consequences of flash flood events (e.g., Guizien et al. 2007). Evidence shows that despite their low magnitude and transient nature, episodic flash-flood events constitute a large proportion of the exchanges along the Mediterranean coasts (Tzoraki and Nikolaidis 2007). A central question to understand the functioning and the response to anthrophization of Mediterranean coastal areas is how and to what extent the ecosystem is regulated by episodic events, and what are the mechanisms that alter the pathways of major nutrients entering the system.

The present work focuses on the nature and relative importance of non-extremal short-term variation in the biogeochemical dynamics of a low-flow Mediterranean estuary, Mahon. In temperate coastal zones, episodic meteorological forcing may have a strong impact on biogeochemical properties and planktonic ecosystem dynamics (Boldrin et al. 2009; Guadayol 
et al. 2009; Malej et al. 1997). Moreover, projections suggest that the Mediterranean is a primary hotspot of climate change (Giorgi 2006) and the distribution frequency of intense atmospheric episodes such as precipitation events is expected to vary in this region (Alpert et al. 2002; Giorgi and Lionello 2008). This episodic variability has an impact on some key ecosystem features such as estuary-ocean exchange, which may influence the ecosystem behavior and water quality. Knowledge on the overall influence of these disturbances on the functioning of these ecosystems is critical to our understanding of their vulnerability to ongoing climate and anthropogenic changes.

\section{Material and Methods}

\section{Site Description}

Mahon is an elongated estuary ( $\sim 5.5 \mathrm{~km}$ long) located in the Island of Minorca (Balearic Islands), in the western Mediterranean Basin (Fig. 1). The peculiarly narrow and deep morphology (max. depth $29 \mathrm{~m}$ ) is conditioned by a W-E running geological fault over which the harbor settles. The main axis of the basin veers slightly $\left(30^{\circ}\right)$ to the south in its outer middle section (from Illa del Rey). The inner sub-basin is shallower (max. depth of $12 \mathrm{~m}$ ) and connected to an ungauged stream that runs through a small agricultural area. Flow is negligible except during major storm events. A watershed with an approximate area of $27.9 \mathrm{~km}^{2}, 18 \%$ of it corresponding to an impervious substrate, drains mainly in the head of the estuary. Owing to the impervious land surface, even minor storms may lead to an increased runoff and small peak flow events. The mouth of the harbor is very narrow $(\sim 300 \mathrm{~m})$ and shoals to $\sim 14 \mathrm{~m}$, thereby constraining the exchange with offshore waters.

Climate in the area is characterized by a strong seasonality, mild wet winters, and warm to hot dry summers. The island is affected by strong Tramontana events, a katabatic (downslope) wind blowing from the north that cools the climate. They occur with greatest frequency in the fall and spring, being less common and weaker in midwinter (January) and summer (see Sup. Fig.1a). A progressive shift to easterly winds, together with a general weakening of wind intensity, is related to the onset of a breeze regime occurring from mid-April to the end of summer. In early fall, and throughout the winter, southeasterly winds blowing towards the estuary entrance also become frequent. Wind from this direction precedes the passage of lowpressure systems from the Iberian Peninsula that is associated with heavy rain episodes (Romero et al. 1998). These SW events do not generally expand for more than 2 days because of the eastward displacement of the depressions (e.g., Doswell et al. 1998; Ramos et al. 2014).

Precipitation is strongly seasonal, with the rainfall season beginning between late summer and early fall. Precipitation is rare from June to late August, whereas records from the National Meteorological Agency (AEMET) reveal high frequency in moderate rainfall events $\left(>10 \mathrm{~mm} \mathrm{day}^{-1}\right)$ from September to December and in spring (Sup. Fig. 1b). Indeed, precipitation during fall is typically a major contributor to the annual precipitation (mean $599 \pm 99 \mathrm{~mm}$ for the period 2000-2015), with $40 \pm 11 \%$ of precipitation occurring between October and December. Coastal water temperature ranges between 12 and $27{ }^{\circ} \mathrm{C}$ throughout the year. Sea level variations are governed by mixed semi-diurnal astronomical tides (amplitude $<0.25 \mathrm{~m}$ ) and similarly important atmospherically forced sea level variations. Since astronomical tidal range is low relative to the depth of the estuary, the tidal prism only represents $0.5 \%$ of the total volume of the basin.

Two urban areas settle along the southern coast, Mahon and Es Castell, with 30,000 residents and 8000 residents, respectively, but total population (residents + visitors) peaks at summer during the high tourism season (2.5-fold winter population). The wastewater effluents of these urban areas are collected through a sewer that discharges offshore, yet, effluents from some buildings in the port area may seep to the estuary representing a minor, but continuous, eutrophication source. These discharges enrich the water at the head of the estuary with nitrate and less so with phosphate (Martínez-Soto et al. 2015). Storm water from impervious urban surfaces flows directly into the bay following the steep coastal topography.

\section{Environmental Data}

Between July 2010 and July 2011, continuous near-surface measurements of temperature and salinity were obtained at 1 min intervals with a SBE-CT installed at the shoreline some $0.6 \mathrm{~m}$ below the sea surface (CT in Fig. 1). Current velocity profiles were obtained at two bottleneck points using bottommounted acoustic doppler current profiler (ADCP) $(1000 \mathrm{kHz}$ Nortek Aquadopp profiler), deployed at depths of 25 (ADCP1) and $8 \mathrm{~m}$ (ADCP2, see Fig. 1). Currents were measured at $1 \mathrm{~m}$ vertical intervals with the first level $1 \mathrm{~m}$ above the bottom. In accordance with the other sampling devices, the temporal sampling interval was also set to $1 \mathrm{~min}$ in both ADCPs. Forty-three temperature and salinity vertical profiles were obtained at each of the three sampling stations (St1, St2, and St3; Fig. 1) at variable intervals spanning from 7 to 10 days, using a YSI CastAway CTD that was deployed slowly to obtain good vertical resolution. The depths at each station were $6 \mathrm{~m}$ at St1, $21 \mathrm{~m}$ at St2, and $27 \mathrm{~m}$ at St3. Underwater irradiance was measured during four seasonal surveys using a Li-Cor spherical sensor and the diffuse attenuation coefficient $(k)$ was calculated from least-square fit of the log-transformed data.

Sea level variations were registered at $5 \mathrm{~min}$ intervals by a MIROS microwave radar recorder located at the inner basin 


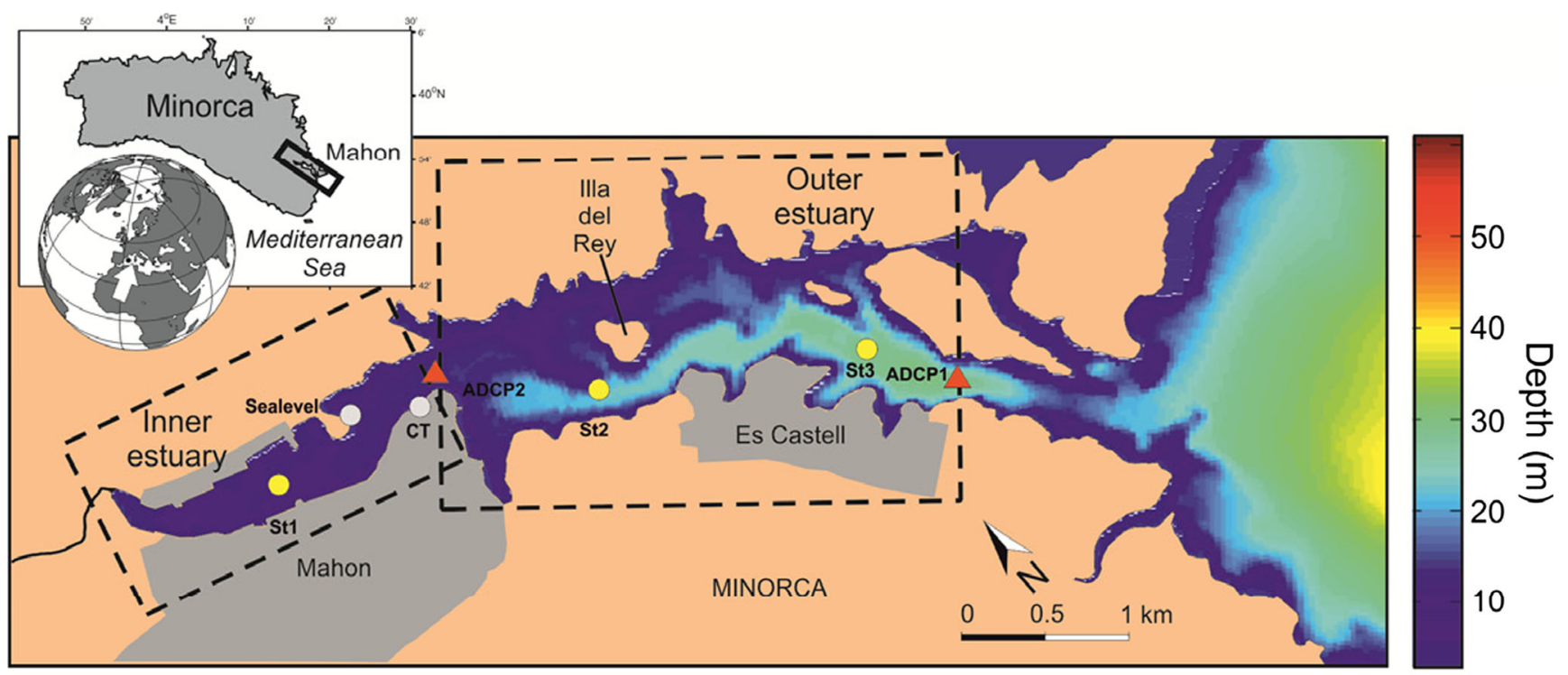

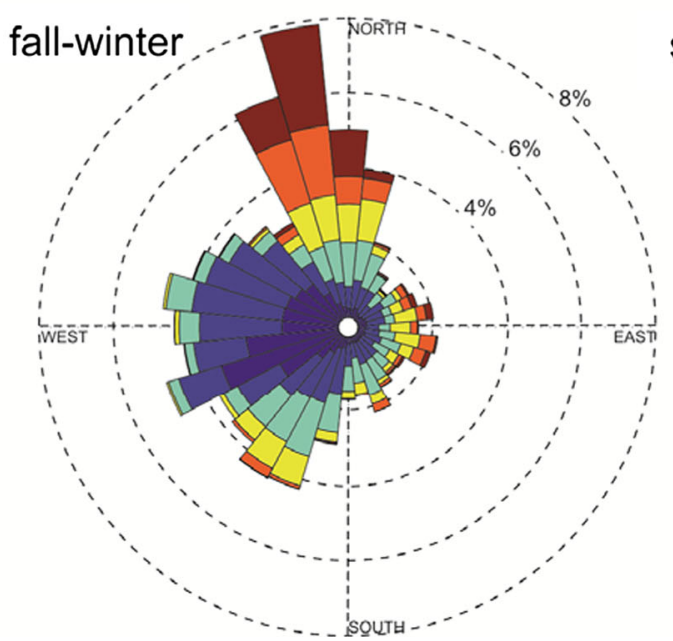

Fig. 1 (Top) Map and bathymetry (m) of Mahon estuary. Dots represent the sampling stations occupied during the various surveys. Time series stations are indicated with yellow dots. Red triangles and cyan dots

(Fig. 1). This instrument is part of the sea level measuring net REDMAR maintained by the National Port Authority Puertos del Estado. Continuous wavelet transforms (CWTs) were used to determine the degree of non-stationary oscillations present in the sea level time series. The application of the CWTs is an effective method of analyzing and synthesizing the variable structure of a signal over time and provides a means of localizing events of interest at their exact temporal location (Torrence and Compo 1998). We used a Morlet wavelet, commonly used in studies of geophysical processes.

To analyze the mass exchange between the estuary and coastal waters, the current flow vector time series for each moored ADCP location was decomposed into an along $(u)$ and cross-channel $(v)$ component. Since our interest was the subtidal variability in the estuary and, in particular, the identification of event-related anomalies, the wind, sea level, and current data sets were low-pass filtered using a 33-h filter to

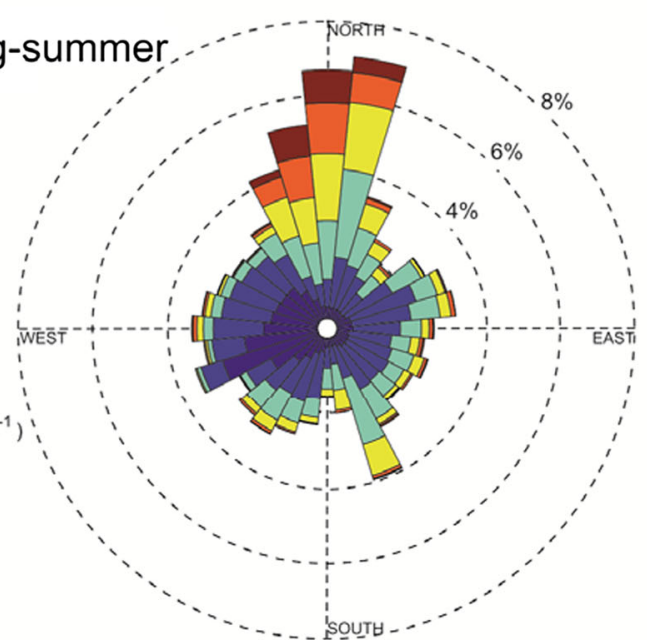

indicate the position of ADCPs, sea level, and CT recorders. (Bottom) Seasonal wind rose diagrams based on $10 \mathrm{~min}$ wind data recorded at Mahon during the present study

remove fluctuations with diurnal or higher frequencies (Beardsley and Rosenfeld 1983). We concentrated our analysis on the study of two periods: one covering the summer until the first autumn rainfall episode (period 1, summer: 2010/07/15 to 2010/10/15) and the other spanning from December to March (period 2, winter: 2010/12/15 to 2011/3/15). We selected these periods because they represent the two seasonal extremes in water column stratification while including relevant meteorological events (i.e., rainfall and wind). Empirical orthogonal function (EOF) analysis was applied to the along estuary component $(u)$ of the current velocity to obtain a representation of the main modes of variability. The EOF analysis decomposes spatial-temporal variations of a geophysical field into combination of orthogonal spatial patterns with corresponding principal components in a linear fashion (Lorenz 1956).

Meteorological data was obtained from the station of Mahon Port Authority located in the mouth of the estuary. 
Additional meteorological data from Mahon Airport located $3.5 \mathrm{~km}$ to the south of the study area were obtained from the Spanish Meteorological Agency (AEMET). We used wind and atmospheric pressure data from the Port Authority because they reflect better the conditions in the coast. However, precipitation measurements of this station were unreliable and, therefore, rainfall data from the Airport was used. Spectral coherence was estimated using sea level and alongaxis current with the wind rotary components as a complex time series (Gonella 1972; Mooers 1973). A Hanning window of 1440 points (10 days) with half window overlapping was applied for all spectral computations, resulting in at least 12 degrees of freedom (dof) for the shorter (winter) time series. Daily flushing time $\left(\tau_{\mathrm{f}}=\right.$ volume/(cross sectional area* $\left.u\right)$ ) for the inner and outer domains of Mahon harbor was estimated from hourly mass exchange estimations through control bottleneck sections at ADCP1 and ADCP2, assuming that flow was homogenous at each depth level. Since the ADCP data does not reach the surface, near-surface current intensities (i.e., $1 \mathrm{~m}$ ) were linearly extrapolated from the levels below. The highest absolute value of the inflow-outflow at each section was used to calculate the exchange between the inner and outer estuaries or between the estuary and the coastal ocean (see Fig. 1). The calculated flushing time values represent an upper-end estimation of the water renewal in the estuary, which is assumed to be lower since a large part of the flux is produced by oscillatory motions that do not produce significant exchange.

\section{Sample Collection and Analysis}

Discrete seawater sampling was carried out simultaneously to CTD vertical profiles. Due to logistic limitations, runoff episodes were characterized by the conditions in the estuary within 3 days after each major rainfall event. At each sampling station (St1, St2, and S3), triplicate surface water samples $(13 \mathrm{ml})$ were collected by hand in acid-washed polyethylene tubes for nutrient analysis. Additionally, seawater samples were obtained at six depths at St3 on 2010/10/21, 2011/03/ 11, and 2011/06/27. A 2.5-1 Niskin bottle was used to obtain these samples. Nutrient samples were pre-filtered through GF/ F fiberglass filters (Whatman Ltd.) and subsequently frozen until analysis. Concentrations of dissolved inorganic nitrogen (DIN; $\left.\mathrm{NO}_{3}{ }^{-}+\mathrm{NO}_{2}{ }^{-}+\mathrm{NH}_{4}{ }^{+}\right)$, phosphate $\left(\mathrm{PO}_{4}{ }^{3-}\right.$ ), and soluble reactive silicates $(\mathrm{Si})$ were measured with an Alliance Futura autoanalyzer following Grasshoff et al. (1983). Total dissolved $\mathrm{P}$ was estimated by pre-oxidizing the sample with an alkaline persulfate digestion that hydrolyzes all forms of inorganic and organic P to orthophosphate. Dissolved organic phosphorus (DOP) was estimated as a difference between TP and DIP. The accuracy of the analysis was established using Coastal Seawater Reference Material for Nutrients (MOOS-1, NRC-CNRC), resulting in 97, 93, 98, and $118 \%$ for $\mathrm{PO}_{4}{ }^{3-}, \mathrm{NO}_{3}{ }^{-}, \mathrm{NO}_{2}{ }^{-}$, and $\mathrm{SiO}_{2}$, respectively. The limit of detection (LOD), calculated as three times the standard deviation of subsequent blank measurements, was $\mathrm{PO}_{4}{ }^{3-}$ : $0.04 \mu \mathrm{M}, \mathrm{NO}_{3}{ }^{-}: 0.001 \mu \mathrm{M}, \mathrm{NO}_{2}{ }^{-}: 0.001 \mu \mathrm{M}, \mathrm{NH}_{4}{ }^{+}$: $0.03 \mu \mathrm{M}$, and $\mathrm{SiO}_{2}: 0.02 \mu \mathrm{M}$ and the precision $<2 \%$ relative standard deviation (RSD) for all nutrients.

Chlorophyll (Chl) concentrations were measured by fluorometric analysis of extracted pigments. About $120 \mathrm{ml}$ was filtered through glass fiber filters (GF/F-Whatman) and stored frozen (Parsons et al. 1984). Pigments were extracted in $90 \%$ acetone and stored in the dark at $4{ }^{\circ} \mathrm{C}$ overnight. The fluorescence of the extracts was measured with a Turner Designs fluorometer calibrated with pure Chl- $a$ (Sigma Co.). The chlorophyll time series was low-pass filtered to separate seasonality from the higher frequency signal at each station.

Samples were collected for the identification and quantification of microplankton assemblages and were maintained in Lugol-iodine solution, sedimented ( $24 \mathrm{~h})$, and a suitable area quantified using a Leica-Leitz DM-IL inverted microscope (Andersen and Throndsen 2003).

\section{Results}

\section{Estuarine Dynamics}

Meteorological observations at Mahon indicate that winds in this region present seasonal differences, being highly variable in speed and direction. As shown in Fig. 1, strongest winds (i.e., $>8 \mathrm{~m} \mathrm{~s}^{-1}$ ), from which the estuary is protected, are predominately from the north and reflect Tramontana wind conditions. Precipitation during the study period $(752 \mathrm{~mm}$ ) was above average (Supp. Fig. 1b). The wet season started relatively late, but rainfall events associated with the passage of atmospheric depression were noticeably intense, particularly between October and December (Fig. 2). Changes in nearsurface salinity reflected the freshwater flow along the estuary in response to these rainfall episodes, and significant negative correlation $(r=0.74, p<0.001)$ was obtained between these surface water salinity variations and moderate rainfall events (accumulated precipitation $>15 \mathrm{~mm} /$ day). Moderate precipitation (>15 mm/day) occurred on 15 days clustered on eight major events, associated with the passage of atmospheric depressions affected the estuary between September and April 2010. Mahon received significant inputs of freshwater during these events, but recovered quickly ( $5 \pm 2.2$ days) leaving only a variable background salinity decline of 0.15 to 0.51 units. Mean surface salinity during the sampling was $37.5 \pm 0.44$ in the inner estuary. Between July and September, salinities in the inner basin exceeded 38.0 revealing scarce freshwater influence. These high salinity conditions were generated at the very slow rate of 0.003 units day ${ }^{-1}$ over the period of a month, presumably by the combined effect of oceanic water intrusion 
Fig. 2 Atmospheric conditions at Mahon during the survey period. a Mean diel wind vector. $\mathbf{b}$ Atmospheric pressure. c Accumulated daily precipitation. d Continuous record of nearsurface salinity at CT. e Water column temperature $\left({ }^{\circ} \mathrm{C}\right)$. Blue and red areas in the salinity figure indicate values below and above the typical range (gray band). Dashed boxes indicate the summer and winter period analyzed in detail. Blue dashed lines mark the approximate limits of the stratified and non-stratified periods
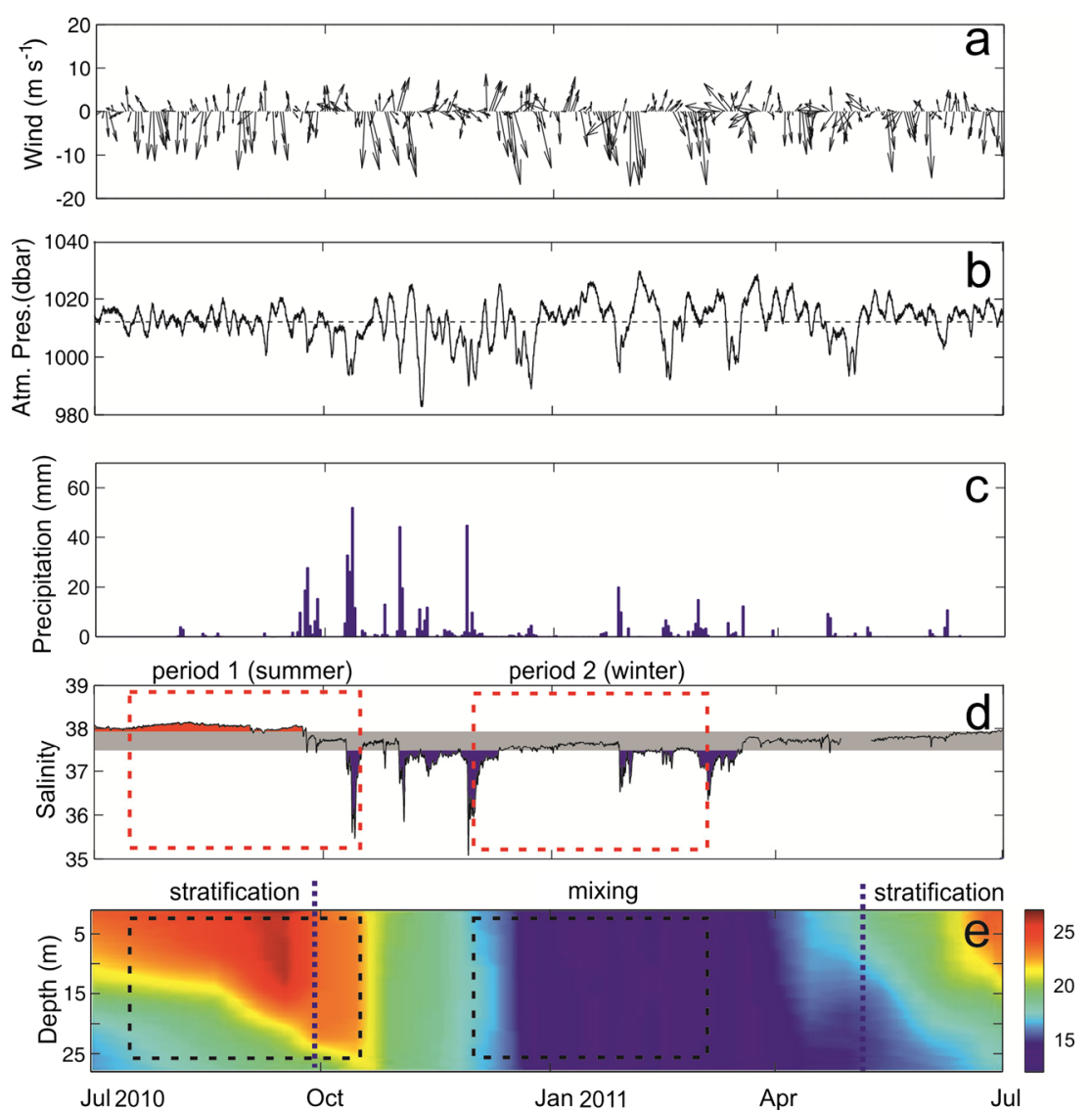

and evaporation, and finished abruptly with the first rainfall event at early fall.

The first rainfall event did not produce a marked salinity variation, most probably because land was dry and warm, and runoff was scarce. Subsequent storms occurring during the fall were most intense, producing a decline in salinity of up to 2.2. From late fall to late spring, temperature and salinity profiles showed minor differences between surface and bottom waters, but during summer conditions changed remarkably and the water column presented intense thermal stratification with a thermocline located at $16.3 \pm 1.0 \mathrm{~m}$ isolating the deepest waters of the harbor. Temperature difference between the upper and lower layers at the beginning of this period exceeded $10^{\circ} \mathrm{C}$ but temperature progressively equilibrated and thermocline deepened by the end of summer.

Figure 3 displays the decomposition of sea level variations into tidal and non-tidal components, illustrating the importance of non-tidal low-frequency variations. Tide was determined by semi-diurnal and tidal constituents (M2, K1, S2, O1, Supp. Table 1) whereas high-frequency sea level oscillations were caused by internal seiching motions peaking at 37,14 , and $8 \mathrm{~min}$. Most notably, subtidal sea level variations exceeding the tidal range were frequent throughout the year, particularly at the end of summer and along the winter. The CWT analysis of these variations highlights the relevancy of the synoptic meteorological scales (i.e., 2 to 5 days) in these sea level variations (Fig. 3c.). Indeed, a correspondence between some rainfall, wind, and atmospheric pressure variations with the energy enhancement at these frequencies can be inferred.

Currents exhibited predominately semi-diurnal fluctuations, but an important subtidal variation was also observed, mostly in an E-W direction being caused by the orientation of the estuary. The EOF decomposition of the subtidal axialcurrent variance for the stratified (summer) and nonstratified period (winter) is displayed in Fig. 4. During stratified conditions, currents below the thermocline $(\sim 16 \mathrm{~m})$ were extremely low $\left(<0.01 \mathrm{~m} \mathrm{~s}^{-1}\right)$ and circulation was highly variable and event-related. Since flow in the deepest layer was negligible, circulation was restricted to two layers above the thermocline. The vertical extension of the deep layer increased as the thermocline deepened after mid-September. The first EOF, capturing $65 \%$ of the variability, reveals the pulsed variation in current intensity together with flow reversals. Although the intensification of some of these flow variations can be associated with some of the observed axial wind patterns (Fig. 4c), the interpretation is not straightforward, and remote processes (i.e., shelf dynamics) could have a strong influence. This is not the case of the second EOF (18\% of the variability) which appears to be associated with local rainfall events. 

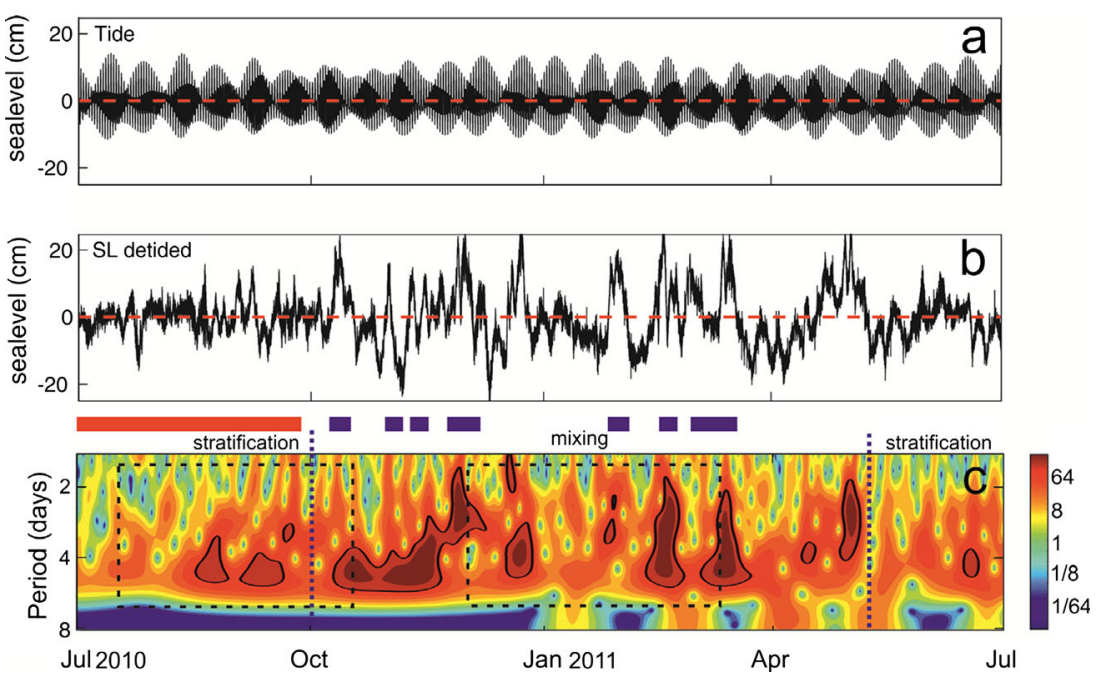

Fig. 3 Sea level variations at Mahon from July 2010 to July 2011. a Astronomical component. b Residual sea level variations. c continuous wavelet transform (CWT) power spectrum of the sea level oscillations. The thick black contours indicate the 95\% confidence level. Dashed boxes indicate the summer and winter period analyzed in detail. Blue

During the second period analyzed (winter), circulation was mainly estuarine and forced by freshwater flow. It is nevertheless striking that circulation rapidly reversed when freshwater flow ceased. The first EOF, representing $76 \%$ of the variability, captures this two-layer estuarine circulation. The second EOF mode corresponds to more episodic forcing
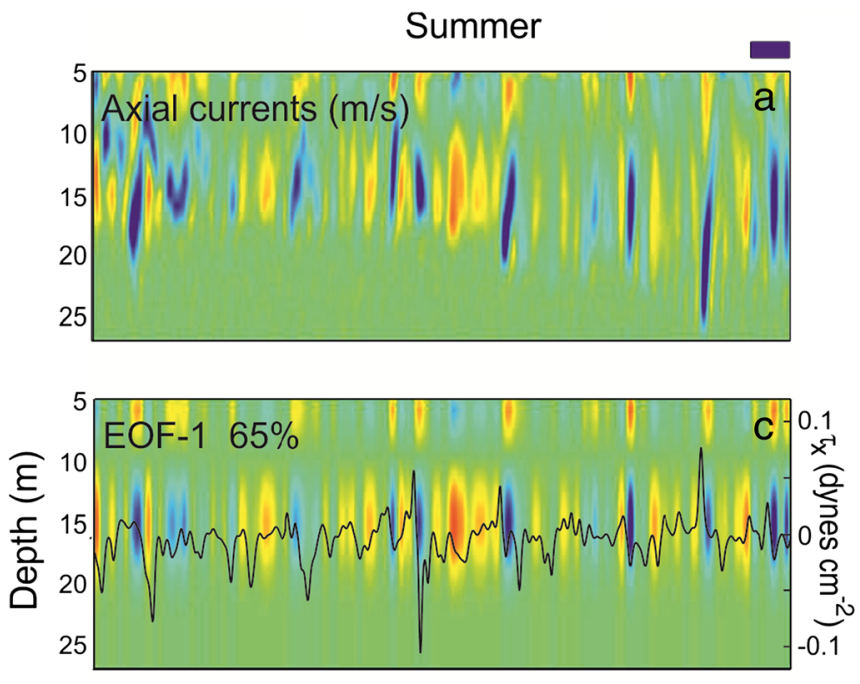

dashed lines mark the approximate limits of the stratified and nonstratified periods. Red and blue stripes at the top indicate periods of positively (red, above typical values) and negatively (blue, below typical values) altered salinity concentrations

producing disturbances at the interface and occasionally provoking three-layered circulation; however, the coherence with local winds is in this case weaker. Current flow at in the inner basin was consistently shown to be very weak (i.e., $<0.06 \mathrm{~m} \mathrm{~s}^{-1}$ ) and generally offshore, causing a surface and bottom compensatory flow.
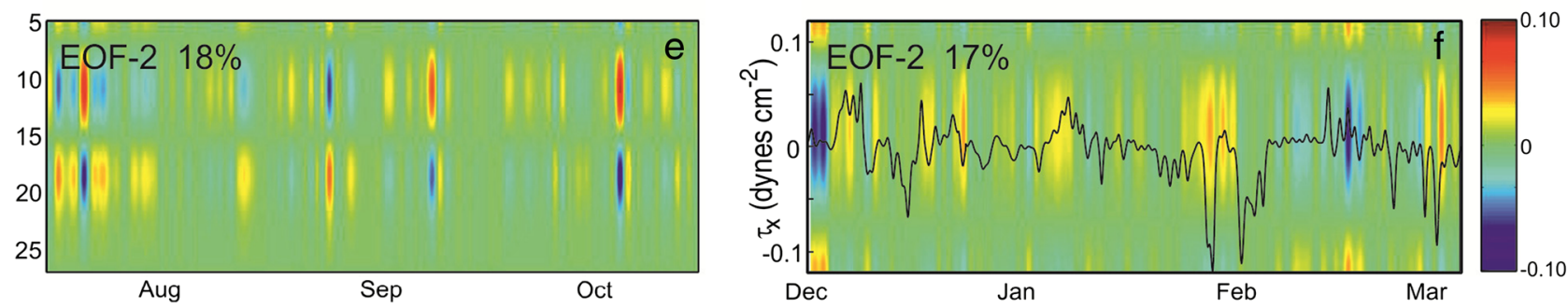

Fig. 4 Filtered ( $33 \mathrm{~h}$ ) current record at ADCP1 and the first two EOF modes during summer stratified $(\mathbf{a}, \mathbf{c}, \mathbf{e})$ and winter non-stratified conditions $(\mathbf{b}, \mathbf{d}$, f). The axial component of wind stress has been overlaid of $\mathbf{c}$ and $\mathbf{f}$. Blue stripes at the top indicate periods of lowered salinity concentrations 
It is rather difficult to disentangle the mechanisms and relative importance through which atmospheric forcing drives circulation in the estuary because, in most of the cases, several processes act simultaneously. However, the importance of some of these processes can be surmised from cross-spectral analyses. For example, as displayed in Fig. 5, the spectral coherence between the clockwise wind and sea level displays peaks at frequencies of some 56 and $24 \mathrm{~h}$. These frequencies agree well with those of island-trapped waves (ITWs) in the area, as described by Jordi et al. (2009a, b). Both ITWs and breeze combine in the 24-h period, which is more energetic in summer, when breeze becomes relevant. The 24 -h peak is also important in driving the flow between the inner and outer basins (at ADCP2) during summer and at the thermocline depth at the estuary mouth (ADCP1). Conversely, the 56-h period seems dominant at this site during winter

In terms of the observed flow, $\tau_{\mathrm{f}}$ ranged from few days to more than 3 weeks (Fig. 6). The higher $\tau_{\mathrm{f}}$ values (i.e., $\tau_{\mathrm{f}}>15$ days) reveal quasi-stagnant situations between flow reversals that do not extend for more than a day. During winter, these transitions presented lower exchange than in summer $\left(\tau_{\mathrm{f}}>23\right.$ days), possibly due to the absence of thermal winds. Conversely, reduced renewal events (i.e., $\tau_{\mathrm{f}}$ from 6 to 15 days) were more frequent in summer when currents regularly reversed. Despite these differences, mean $\tau_{\mathrm{f}}$ was only slightly higher in summer than in winter and differences were not significant $(9.4 \pm 5$ and $8.1 \pm 5, p>0.05)$.

\section{Macronutrient Variability}

Overall, the Mahon estuary was enriched in dissolved inorganic nitrogen and less so in $\mathrm{Si}$ with respect to open coastal waters. As shown in Table 1, an inshore-offshore gradient was observed in most nutrient levels revealing that land sources are a major regulator of the biogeochemistry. Also, as many coastal areas in Balearic Islands (e.g., Basterretxea et al. 2010), the estuary is deficient in inorganic P particularly in its inner basin, where N:P ratios exceed 100. Mean DIN and DIP concentrations at the sampling points revealed these spatial differences and, also, the seasonal pattern (Table 1). $\mathrm{N}$ and $\mathrm{Si}$ increased in the fall and spring during the periods of reduced salinity, peaking during the major rainfall events, whereas P mainly increased during the heavy rains in fall and only marginally in spring (Fig. 7). An exception was ammonium which presented marked seasonality, being the dominant nitrogen form in summer and declining to marginal levels when the water column was mixed $(<0.5 \mu \mathrm{M})$. Average phosphate concentrations were low, but mean concentrations doubled in the fall when runoff was more permanent (Table 1). DOP was consistently higher (mean $0.23 \pm 0.09 \mu \mathrm{M}$ ) and, therefore, DIP only comprised some $28 \pm 18 \%$ of total phosphorus. However, rainfall events significantly varied the relative amount of DIP to TP (Fig. 7c).
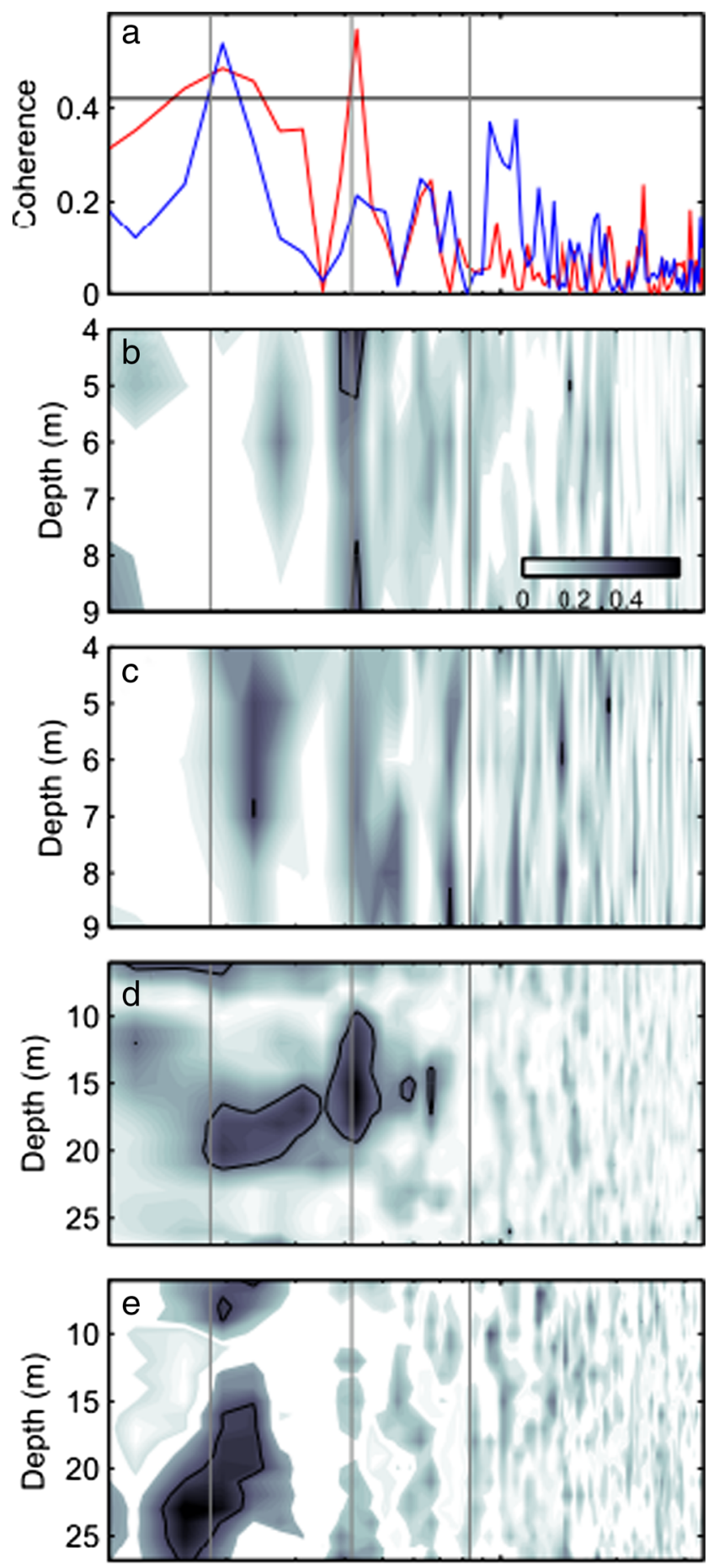

Frequency (cph)

Fig. 5 Spectral coherence between clockwise wind and a summer (period 1, red line) and winter (period 2, blue line) sea level, b summer along-axis current at ADCP2, $\mathbf{c}$ winter along-axis current at ADCP2, d summer along-axis current at ADCP1, and $\mathbf{e}$ winter along-axis current at ADCP1. Vertical gray lines are periods of 56.9, 24.1, and $12.4 \mathrm{~h}$. Black lines represent the $95 \%$ confidence limit

The vertical profiles shown in Fig. 8 reveal the water column changes and associated nutrient and Chl variations occurring in the estuary. The water column was thermally 


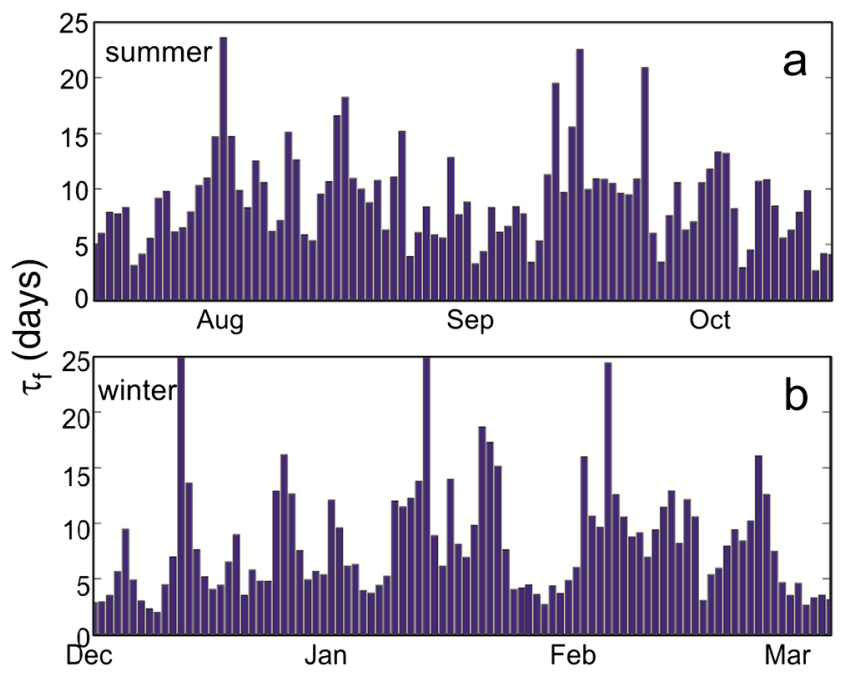

Fig. 6 Daily variation of $\tau_{f}$ (days) based on data from ADCP1 corresponding to the a summer and $\mathbf{b}$ winter periods

stratified in June and the thermocline separated an upper layer with relatively low nutrients from a deeper layer where nitrate and silicate were more abundant, reaching concentrations above $3.0 \mu \mathrm{M}$ near the bottom. Ammonium represented $78 \%$ of DIN in this lower layer during this season. These vertical hydrographic and nutrient differences rapidly homogenized in October. During winter, nitrate and silicate were highest at surface, where a lower salinity layer was present. This is consistent with runoff being a main source of nitrate and silicate. DIP was also enhanced in this lower salinity layer but the increase was very weak $(0.1 \mu \mathrm{M})$ at the sampling point (St 3).

Figure 9 shows the differences in the nutrient molar ratios along the estuary. Because of the persistently high nitrate and silicate concentrations at St1, the inner sub-basin was Plimited (N:P >16) for most of the time. This is consistent with results based on alkaline phosphatase activity obtained by Martínez-Soto et al. (2015) at this site. N limitation was marginal and some episodic increases in P, while reducing P limitation drove the system towards Si deficiency. P limitation was also the most common state at $\mathrm{St} 2$ and $\mathrm{St} 3$, but N:P ratios were reduced in the offshore direction whereas $\mathrm{Si}+\mathrm{N}$ colimitation became more frequent.

\section{Runoff Episodes and Associated Loads}

Generally, inorganic nutrients were very responsive to runoff events, but there was not a good correlation between the salinity decline $(\Delta S)$ and the nutrient concentrations in the estuary. The influence of runoff was particularly noticeable in the case of DIN and Si, but less so in the case of P. Indeed, differences in DIN and Si between St 1 and St 2 correlated well $(r=0.83, p<0.01)$ except when DIN exceeded $6 \mu \mathrm{M}$ during the rainfall episodes in fall. In these events, the nutrient ratios were substantially altered towards an excess of DIN. This was consistent with the elevated nitrate concentrations measured in the torrent $(133-150 \mu \mathrm{M})$, which is presumably enriched by agricultural loads and decaying plant matter in the lower section of the watershed. Phosphorus was only significantly enhanced during the most intense rains in the fall but otherwise it was present in concentrations at the limit of detection $(0.04 \mu \mathrm{M})$. As a consequence, runoff had the potential of increasing the already existing phosphorus limitation.

\section{Biological Conditions}

Chlorophyll concentration within the estuary varied between 0.74 and $12.7 \mathrm{mg} \mathrm{m}^{-3}$, displaying marked spatial differences. Mean Chl was generally, though not always, enhanced in the

Table 1 Seasonal changes of near-surface nutrient and chlorophyll concentrations in the three sampling stations

\begin{tabular}{|c|c|c|c|c|c|c|c|c|c|c|c|}
\hline \multirow[t]{2}{*}{ Season } & \multirow[t]{2}{*}{ Station } & \multicolumn{2}{|c|}{ Nitrate $[\mathrm{uM}]$} & \multicolumn{2}{|c|}{ Ammonium $[\mu \mathrm{M}]$} & \multicolumn{2}{|c|}{ Phosphate $[\mu \mathrm{M}]$} & \multicolumn{2}{|c|}{ Silicate $[\mathrm{uM}]$} & \multicolumn{2}{|c|}{$\mathrm{Chl}\left[\mathrm{mg} \mathrm{m}^{-3}\right]$} \\
\hline & & Mean & Range & Mean & Range & Mean & Range & Mean & Range & Mean & Range \\
\hline \multirow[t]{3}{*}{ Summer } & St1 & 2.26 & $0.94-4.62$ & 3.79 & $1.00-7.23$ & 0.06 & $0.04-0.14$ & 1.64 & $0.43-2.76$ & 4.92 & $2.84-9.46$ \\
\hline & St2 & 0.29 & $0.06-0.58$ & 2.73 & $1.99-4.22$ & 0.06 & $0.04-0.15$ & 1.16 & $0.48-3.50$ & 4.50 & $2.20-5.73$ \\
\hline & St3 & 0.06 & $0.01-0.13$ & 1.95 & $1.00-2.97$ & 0.05 & $0.04-0.18$ & 0.63 & $0.27-1.10$ & 2.29 & $0.99-4.48$ \\
\hline \multirow[t]{3}{*}{ Fall } & St1 & 11.04 & $2.56-37.32$ & 1.90 & $0.01-6.66$ & 0.26 & $0.04-1.08$ & 3.86 & $1.20-11.65$ & 2.15 & $1.11-3.72$ \\
\hline & St2 & 3.87 & $1.06-13.83$ & 1.17 & $0.01-3.92$ & 0.11 & $0.04-0.35$ & 1.55 & $0.14-6.27$ & 4.18 & $1.45-12.71$ \\
\hline & St3 & 1.58 & $0.18-6.79$ & 1.11 & $0.01-3.64$ & 0.11 & $0.04-0.40$ & 0.89 & $0.30-1.97$ & 3.26 & $1.40-9.34$ \\
\hline \multirow[t]{3}{*}{ Winter } & St1 & 6.78 & $3.58-12.81$ & 0.90 & $0.04-5.62$ & 0.05 & $0.04-0.11$ & 2.41 & $1.07-6.29$ & 2.44 & $1.35-3.79$ \\
\hline & St2 & 2.57 & $1.41-3.69$ & 0.18 & $0.01-0.81$ & 0.05 & $0.04-0.07$ & 1.03 & $0.14-2.80$ & 2.28 & $0.74-3.12$ \\
\hline & St3 & 1.16 & $0.35-1.92$ & 0.12 & $0.01-0.48$ & 0.05 & $0.04-0.08$ & 0.68 & $0.12-1.32$ & 2.01 & $0.86-2.62$ \\
\hline \multirow[t]{3}{*}{ Spring } & St1 & 2.93 & $0.83-4.90$ & 0.46 & $0.07-1.23$ & 0.05 & $0.04-0.13$ & 1.68 & $0.38-2.96$ & 2.59 & $1.47-5.53$ \\
\hline & St2 & 0.51 & $0.01-1.64$ & 0.27 & $0.05-0.83$ & 0.04 & $0.04-0.06$ & 0.82 & $0.14-1.76$ & 2.06 & $0.96-3.37$ \\
\hline & St3 & 0.29 & $0.03-1.27$ & 0.31 & $0.08-0.76$ & 0.04 & $0.04-0.08$ & 0.61 & $0.25-1.36$ & 1.07 & $0.71-1.55$ \\
\hline
\end{tabular}


Fig. 7 Temporal variation of nutrients at Mahon. Values of a) DIN, b) $\mathrm{NH}_{4}$ :DIN ratio, c) DIP, and d) Silicate, at St1, St2 and St3. Concentrations have been normalized to the maximum value for comparison reasons. Red and blue stripes indicate periods of positively (red, above typical values) and negatively (blue, below typical values) altered salinity concentrations. Absolute values were always higher in the head of the estuary (St1) and decreased towards the sea. Therefore, for comparison reasons, concentrations have been normalized to the maximum value at each station. Bars in $\mathbf{c}$ indicate the $\%$ or DIP relative to total phosphorus concentration, right axis
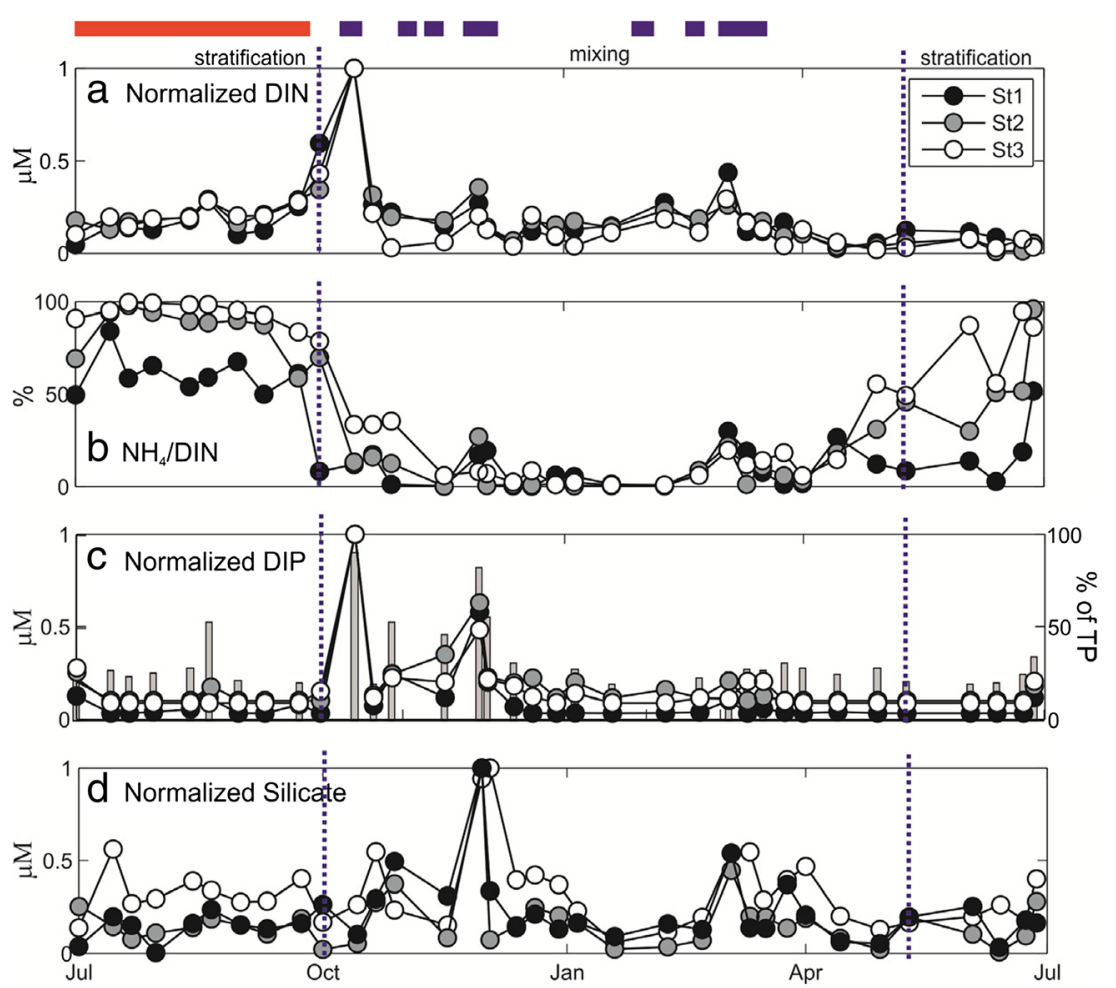

inner station and decreased towards the estuary mouth (Table 1). Light attenuation coefficient $\left(k, \mathrm{~m}^{-1}\right)$ also varied from 0.3 to $0.5 \mathrm{~m}^{-1}$ in the innermost station (St1) and decreased to $<0.25 \mathrm{~m}^{-1}$ at $\mathrm{St} 3$ and presented reasonable correlation with chlorophyll $\left(r^{2}=0.8\right)$, except when runoff was active and $k$ values exceeded 0.4 in the inner harbor, revealing strong influence of riverine dissolved and non-biogenic particulate materials in the light field at St1.

During fall, intense chlorophyll enhancements developed in the middle of the estuary in response to water column mixing and intense rainfall episodes. Seasonality represented between 35 and $48 \%$ of the variance being lower at St 3 where the estuarine processes are attenuated by the greater influence of offshore waters. Chlorophyll concentration was enhanced throughout the summer and the seasonal (low frequency) variation in biomass peaked at the end of the season (except at St3), with the end of the stratification period (Table 1 and Fig. 10). This seasonal trend contrasts with the canonical pattern of offshore blooms which occur regionally in mid-winter (January-February, Jordi et al. 2009b). Maximum Chl concentrations at St2 and St3 occurred when the water column mixed at the beginning of October (see also Fig. 8). Conversely, St1 seemed more influenced by other processes, possibly of biological nature, producing short span blooms during summer. Indeed, strong rainfall generally produced a decrease in biomass at this site.

Phytoplankton taxa responded to shifts in the conditions of the estuary rather than to episodic forcings. Motile taxa such as dinoflagellates and coccolithophorids prevailed throughout the year, whereas diatoms (mainly Thalassionema sp. and Thalassiosira sp.) were only present during early fall when the surface water cooled down and the water column mixed (Fig. 10). Low diatom abundance was attributed to the low Si availability, since diatoms require a $\mathrm{Si}: \mathrm{N}$ ratio of $\sim 1$ to grow (Dortch and Whitledge 1992) and, thus, were not able to compete effectively with species without a Si requirement. Also, it is noteworthy that while similar abundances of dinoflagellates and coccolithophorids were present during spring and through summer, the latter was dominant in the fall $(>90 \%)$, when nutrient concentrations were at their highest.

\section{Discussion}

\section{Estuarine Dynamics}

The present study has investigated the dynamics of a low-flow Mediterranean estuary for the purpose of understanding the relevance of episodic forcing. The equilibrium between seasonal processes and episodic events molds the biogeochemistry of Mahon and its various ecological roles. Generally, strong seasonal patterns develop where the governing processes are linked to the annual climate cycle, and large event-scale variability occurs at sites highly enriched with nutrients (Cloern and Jassby 2010). Mahon responds to both of these paradigms; it displays intense seasonality that determines the general flow patterns in the estuary and overlying remarkable event-scale chemical and biological departures from the basal 

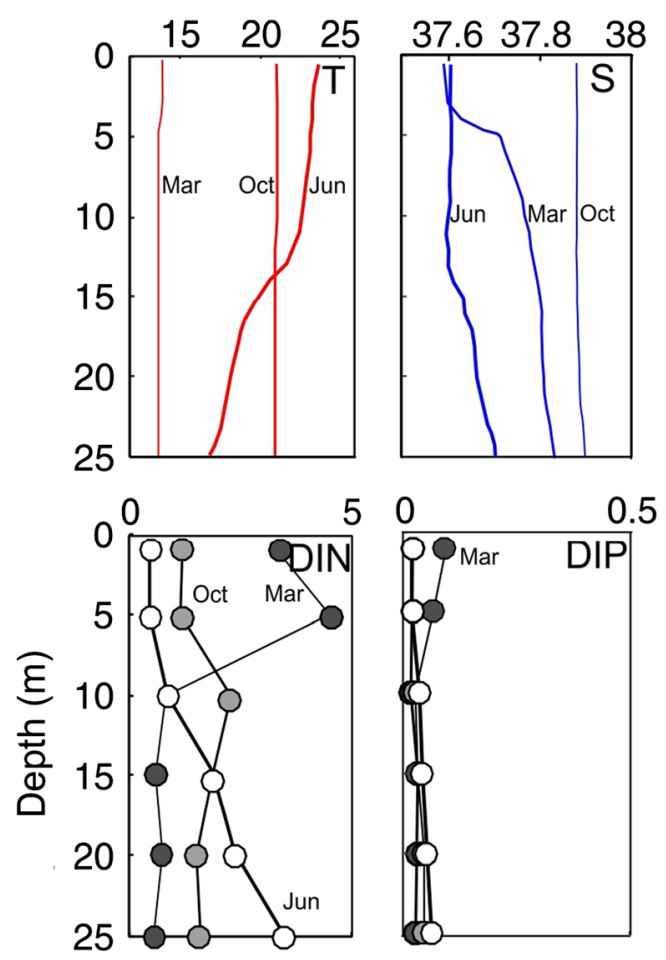

$5 \quad 0 \quad 0.5$
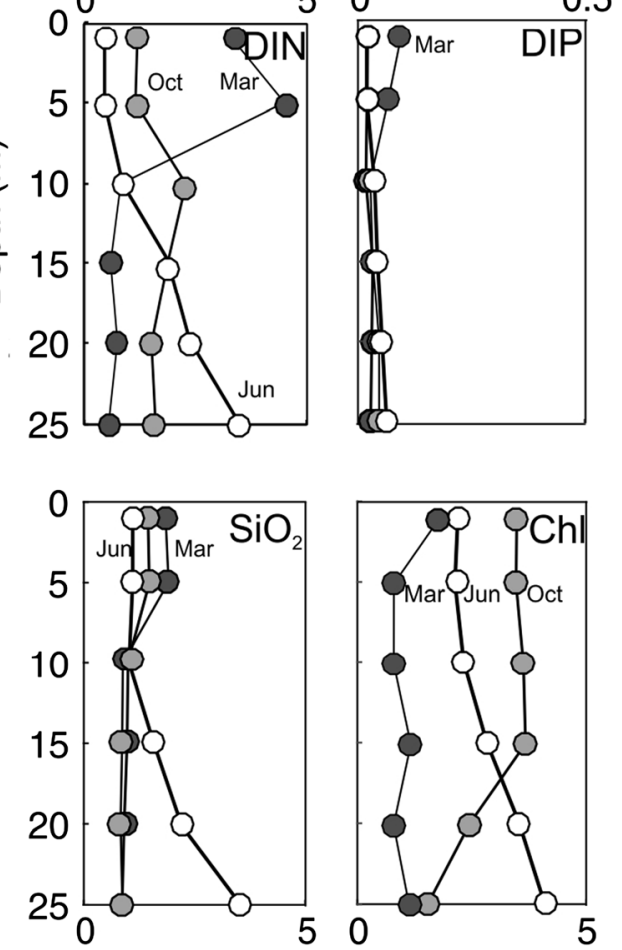

Fig. 8 Vertical profiles of temperature $\left({ }^{\circ} \mathrm{C}\right)$, salinity, DIN $(\mu \mathrm{M})$, DIP $(\mu \mathrm{M})$, silicate $(\mu \mathrm{M})$, and chlorophyll $\left(\mathrm{mg} \mathrm{m}^{-3}\right)$ at St3 during October 2011, March 2011, and June 2011

state (defined as the system state during low runoff and weak atmospheric forcing conditions).

The degree of connectivity with the adjacent catchment and the sea, as well as the loads of the associated exchanges, determines the environmental conditions in an estuary. Our data reveals that, despite the daily flushing time being similar in the two periods analyzed, the hydrodynamic functioning of Mahon varies dramatically from summer to winter. It also varies seasonally in the degree of marine influence from fully marine in summer to lowered salinity conditions (salinity <37) later in winter. Summertime dynamics is characterized by negligible runoff, which has profound effects on the circulation pattern of the estuary that relies on oscillatory motions forced by local and remote (i.e., through ITWs) wind forcing. In this sense, the existence of increased wind episodes and their frequency becomes fundamental to the flushing of the
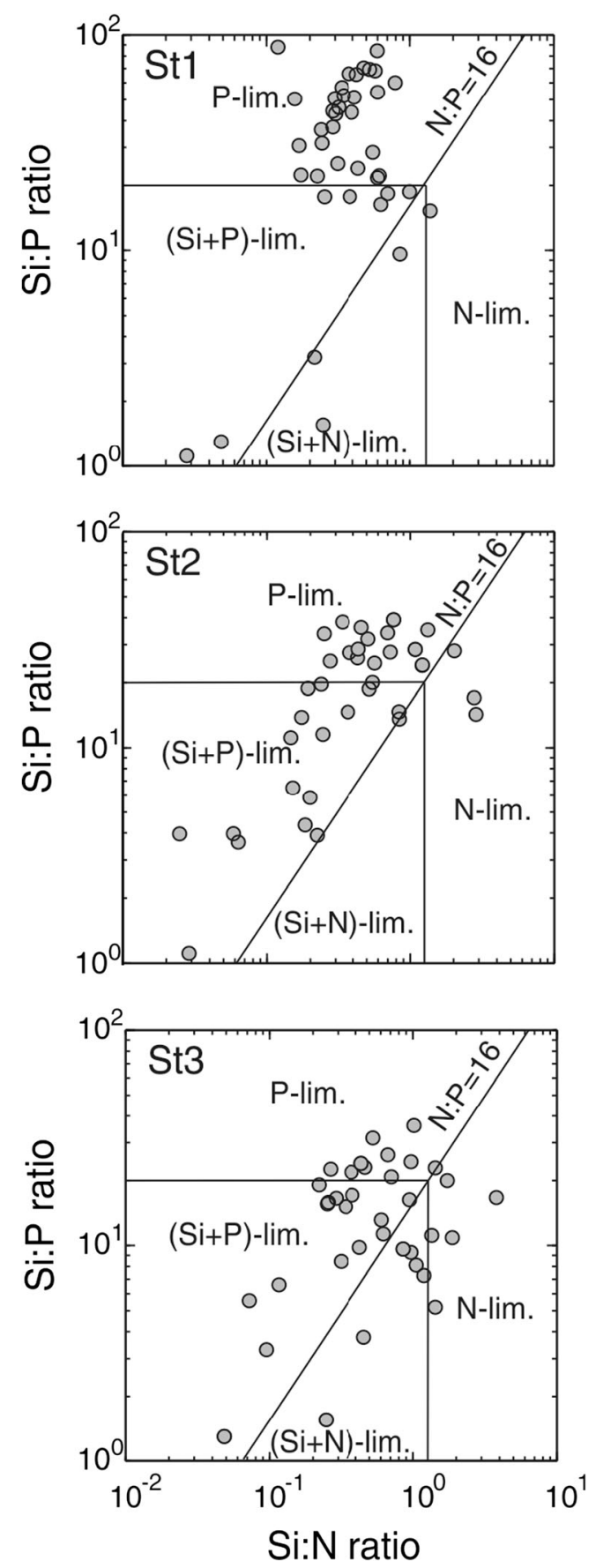

Fig. 9 Molar ratios of dissolved inorganic nutrients at the three sampling points in Mahon estuary (St1, St2, and St3). The lines separate four theoretical zones representing areas with different nutrient limitations according to canonical Redfield ratios

estuary. Geyer (1997) analyzed strong influence of local wind in the flushing of two estuaries in Waquoit Bay (USA) that was dependent on their shallow depths and geomorphologic constrains. The case of Mahon is somewhat different because of its greater depth (up to $29 \mathrm{~m}$ ), and yet, the intense summer stratification decouples the surface waters, which are subjected to wind dynamics, from the subsurface layer that remains stagnant (Fig. 4a). This facilitates the response of the estuary 
Fig. 10 Temporal variation of chlorophyll $\left(\mathrm{mg} \mathrm{m}^{-3}\right)$ at Mahon and main microphytoplankton taxa (\%) at St2. Chlorophyll is represented in a logarithmic scale. Red and blue stripes indicate periods of positively (red, above typical values) and negatively (blue, below typical values) altered salinity concentrations. Continuous lines represent the low-frequency (i.e., seasonal) component of the variability at each station

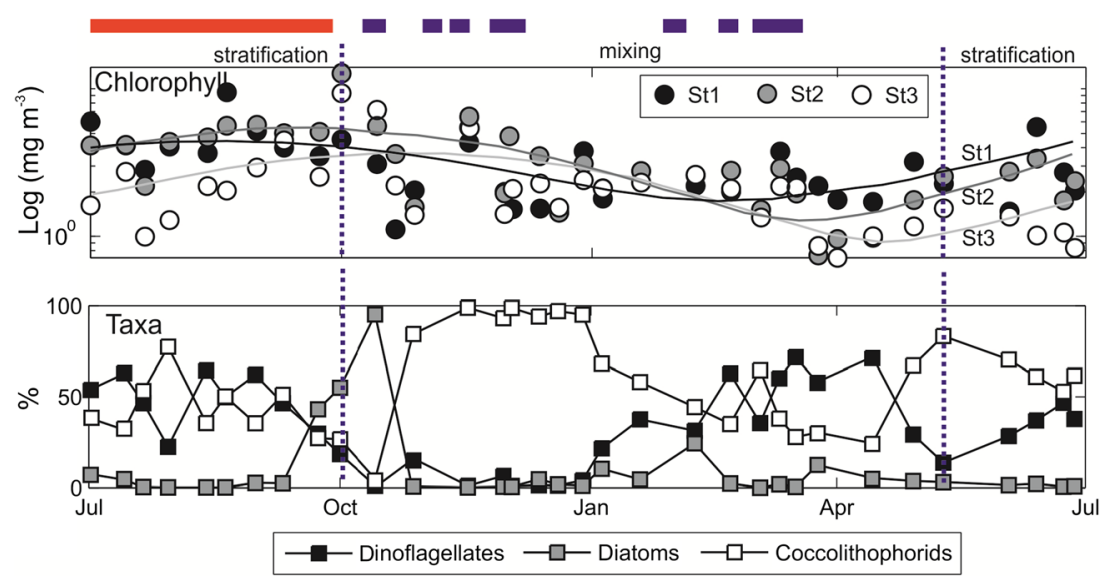

to wind forcing which is also favored by the low horizontal density gradient that accentuates the relative influence of wind stress over the gravitational component. Although perturbed by other effects, the EOF analysis shows this local wind induced modulation in the strength of the estuarine flows, also suggesting flow reversal during the relaxation periods after some episodes (see Fig. 4c).

The relevance of local wind in the flushing of Mediterranean estuaries has been previously acknowledged (e.g., Hearn and Robson 2002); however, less is known on the effects of trapped waves. O'Callaghan et al. (2007) observed that remotely forced shelf waves were important for the circulation and water properties of a microtidal estuary in Western Australia. We also found that oscillatory motions in the range of 1-3 days were an important component of flushing. Nevertheless, it is uncertain to what extent these back and forth motions affect the residence time and thus the environmental state of the waters in an elongated estuary such as Mahon, particularly in its inner section. Indeed, Rodellas et al. (2015), based on radium isotope techniques, estimated higher mean water ages at Mahon in summer ( $6.7 \pm 1.8$ days) than in other seasons (4.2 and 2.3 days). This suggests that despite the comparable $\tau_{\mathrm{f}}$, water renewal might be, in fact, weakened in summer. Dependence of $\tau_{\mathrm{f}}$ on wind forcing implies that prolonged wind weakening periods may result in reduction in flushing by seawater and consequent enhancement of problems related to nutrient enrichment and associated eutrophication in this season.

Unlike in the summer, wet season dynamics at Mahon is conditioned by rainfall events and, as in most estuaries, freshwater discharge, and gravitational circulation dominate the circulation (e.g., Dyer 1997). The wavelet analysis revealed narrow coupling between sea level variations and rainfall events in the period range of 2 to 6 days but, even more important than the rainfall episodes themselves, is the overall effect of runoff on the estuarine circulation. This variation in the importance from short- to long-term forcing is evidenced in the comparison between summer and winter flow shown in Fig. 4. However, because of the small catchment and rainfall irregularity, this type of circulation may dramatically weaken during some periods in winter (i.e., on January) and also presents strong variability. This high degree of stochasticity in the riverine flows makes it difficult to obtain generalized patterns of estuarine functioning throughout the winter.

\section{Biogeochemical Effects}

Two major nutrient sources with their associated temporal variability overlap at Mahon: diffuse urban effluents and nutrients in runoff events. These sources, together with the internal biogeochemical mineralization processes, determine the nutrient balance of the estuary. The wet season is dominated by reduced biological activity (i.e., 43 to $52 \%$ of summer phytoplankton biomass), surface water outflow, and water column mixing. In contrast, summer is an environmentally vulnerable period at Mahon because the long-term exchange of suspended and dissolved matter is driven by weather stochasticity (i.e., episodic events) and oscillatory motions. Apart from the reduced nutrient loads, the major geochemical variation in this season is the increased $\mathrm{NH}_{4}$ concentration (see Table 1), which suggests intensive nitrogen recycling in the estuary and/or decrease of the nitrification rates of diffuse urban effluents. Low inorganic phosphorus concentrations also indicate that internal biogeochemical mineralization and/or organic P sources may be fuelling the phytoplankton standing stock throughout the summer. As a result of the increased biological activity within the estuary during this season, phytoplankton is able to fully assimilate the external nutrient loads (see summer nutrients in Table 1). This provokes a marked contrast with the biological conditions offshore, characterized by low chlorophyll values (i.e., Jordi et al. 2009b), evidencing a human-induced shift in the canonical patterns of the coastal environment. Also, the dominance of dinoflagellates (40 to $60 \%$ of total microplankton cells) during this season could respond to their efficiency in the use of regenerated nutrients (Smayda 1997; Pitcher et al. 1998). Overall, this reflects a 
change in the estuary role from a transition ecosystem (i.e., sensu Levin et al. 2001) to a self-contained system.

Overlapped on this seasonal trend, runoff episodes suppose large departures from basal nutrient levels exceeding the longterm annual nutrient load. In this semi-arid watershed, the nutrient flux during each episode is not linearly related to precipitation intensity and more complex relationships between precipitation and freshwater loads become necessary to explain runoff discharges into the estuary (i.e., duration, storm trajectory across the watershed, soil saturation). Precipitation events have short-term effect on the biogeochemistry of the estuary and also a longer-term influence that depends on the combined effects of a sequence of storms. Long-term records from AEMET show that between 15 and 30 moderate precipitation days (> $10 \mathrm{~mm} /$ day) occur each year at Mahon clustered in 5 to 12 major precipitation events mainly occurring between late summer and late spring (mean $8.5 \pm 2$ events). This suggests that on average year, conditions should not be very different from those observed during the present survey. Only in driest years such as 2000 or 2012, with accumulated precipitations of 419 and $360 \mathrm{~mm}$, winter estuarine circulation could be endangered.

There is profuse evidence of short-lived water quality changes in estuaries in response to storms and floods (Eyre and Ferguson 2006; Tomasko et al. 2006; Valiela et al. 1998). A main feature of episodic freshwater inflow is its substantial impact on residence time. Suspended particulates, nutrients, and biota are flushed out of the estuary during the strong rainfall episodes. During these events, the estuary acts mainly as a conduit, although some physical and biological filtering occurs within the system. Some nutrients remain for sufficient time to stimulate positive phytoplankton responses, and changes in phytoplankton composition following event-scale perturbations have been documented in other estuarine systems when conditions stabilize (e.g., Pinckney et al. 1999) but these alterations are usually temporary. Transient responses of the phytoplankton community composition to episodic forcing have been shown in field studies and simulation models revealing tight coupling between the environmental variables, and the phytoplankton response at the time scale of few days (i.e., Nakane et al. 2008). However, as reported for other estuaries (Hall et al. 2013), our results demonstrate a stronger linkage between the phytoplankton community and climatic drivers such as flow, temperature, or stratification. The considerable capacity of Mahon to recover from these point disturbances could be related to its relatively large volume that buffers peak events.

Our data also reveals that the timing of runoff events is relevant. For example, runoff episodes occurring at the end of the stratified season present higher biological response than those occurring in winter. This is more evident at St2, in the middle of the estuary which is less influenced by other factors such as increased turbidity, often occurring at St1 or by dilution with offshore waters. This seasonally varying response to increased precipitation has also been observed by Thompson et al. (2015). Similarly, it has been suggested that tropical cyclones which strike temperate estuaries in late fall may have a less severe effect on water quality than do those that occur during warmer summer months (Mallin et al. 2002).

Despite the fact that particular events may not provoke long-term responses in the plankton assemblage composition, their impact can be evaluated by their overall effect. For example, recurrent freshwater discharge may be considered as a disturbance factor that leads to a regular setback of community development, while maintaining the system in an immature state (Stanley 1973). Also, the combined effect of several episodes may produce long-term changes in the biochemistry of the estuary. In our case, runoff mainly provides nitrogen and, less so, other elements such as Si. Silica in rivers originates mainly from rock weathering, and direct inputs through urban or industrial wastewater discharge are minor (Garnier et al. 2006; Sferratore et al. 2006). Excess supply of these nutrients represents a fundamental difference in the biogeochemical functioning of the estuary, which is dependent on $\mathrm{P}$ availability, with respect to open coastal waters, where inorganic nitrogen is scarce. Phosphorus deficiency does not represent a limiting factor for overall phytoplankton growth, but it triggers the use of alternative $\mathrm{P}$ sources resulting in variations in the competitive advantages of the different phytoplankton species (Martínez-Soto et al. 2015). Indeed, while Mahon is a net exporter of inorganic nitrogen, it either scavenges $\mathrm{P}$ from nearby coastal waters or relies in the $\mathrm{P}$ supply from human activities either in organic or inorganic forms.

There is a range of climate change-related mechanisms through which the estuarine water biogeochemistry is anticipated to be affected, including temperature increase, changes in the hydrological cycle, modification of wind patterns, and sea level rise (Scavia et al. 2002; Rabalais et al. 2009). From these, changes in wind, in temperature, and in hydrology seem to be critical for Mahon. As discussed, wind is a major regulator of the water renewal at Mahon, and therefore, changes in the wind regime could dramatically alter flushing during the low-flow season. Also, apart from the complex effects that are anticipated over estuarine biodiversity and ecosystem metabolism, increasing temperatures will lead to increased thermal stratification and to the expansion of the stratified season. This is rather critical because a prolonged isolation of the deep layer together with a reduction in the vertical exchange could result in anoxic events within the estuary. Likewise, reduced mixing would favor a concentration of nutrients in the upper layer and an enhanced biological activity. Finally, changes in precipitation timing and intensity can also alter the biological cycling. Rainfall in summer, when plankton communities are more responsive to external inputs, could result in intense blooms. Conversely, sustained drought in winter would suppose a loss of the estuarine circulation at Mahon. Decreased 
salinity areas represent an essential habitat for the reproductive ecology of several organisms in the Mediterranean Sea (Palomera 1992; Alemany et al. 2006).

In conclusion, Mahon is an anthropic system in which, as many other Mediterranean areas, phytoplankton seasonality has shifted from the typical winter bloom into a summer biomass maximum. Approximately 59\% of the chlorophyll variability corresponds to no seasonal signal driven by eventscale physical and biogeochemical processes such as flushing time variations or nutrient enrichment. Even so, the ecosystem seems to be quite resilient to these episodes. However, the summer season is a vulnerable period both because renewal depends critically on wind forcing, and because eventual rain episodes produce stronger biotic response than in other seasons. Alteration of the magnitude, frequency, and duration of these disturbance regimes in this season could provoke marked changes in the behavior of the estuary. These findings point to a critical issue that merits further investigation.

Acknowledgements This work was financed by the "Ministerio de Economía y Competitividad" MINECO grants EHRE (CTM200908270) and GRADIENTS (CTM2012-39476-C02-01). A Jordi's work was carried out under a Ramón y Cajal contract from the Spanish Ministry of Economy and Competitiveness. We are indebted to "Puertos del Estado" and "Autoritat Portuaria de Balears" for support during sampling and providing data from their archives. We are also grateful to Rafael Quintana, Itziar Álvarez, and Ana Massanet for assistance in fieldwork. Meteorological data were provided by the "Agencia Estatal de Meteorología (AEMET)" and sea level data by the "Puertos del Estado," and watershed information was obtained from the IDE-Menorca (Consell Insular). We are grateful for the constructive comments of the two anonymous reviewers.

\section{References}

Alemany, F., S. Deudero, B. Morales-Nin, J.L. López-Jurado, J. Jansà, M. Palmer, and I. Palomera. 2006. Influence of physical environmental factors on the composition and horizontal distribution of summer larval fish assemblages off Mallorca island (Balearic archipelago, Western Mediterranean). Journal of Plankton Research 28: 473-487.

Alpert, P., T. Ben-Gai, A. Baharad, Y. Benjamini, D. Yekutieli, M. Colacino, L. Diodato, C. Ramis, V. Homar, R. Romero, S. Michaelides, and A. Manes. 2002. The paradoxical increase of Mediterranean extreme daily rainfall in spite of decrease in total values. Geophysical Research Letters 29: 1536. doi:10.1029/2001GL013554.

Andersen, P., and J. Throndsen. 2003. Estimating cell numbers. In Manual on harmful marine microalgae, ed. G.M. Hallegraeff, D.M. Anderson, and A.D. Cembella, 99-129. Paris: UNESCO Publishing.

Arin, L., J. Guillén, M. Segura-Noguera, and M. Estrada. 2013. Open sea hydrographic forcing of nutrient and phytoplankton dynamics in a Mediterranean coastal ecosystem. Estuarine, Coastal and Shelf Science 133: 116-128.

Basterretxea, G., A. Tovar-Sanchez, A.J. Beck, P. Masqué, H.J. Bokuniewicz, R. Coffey, C.M. Duarte, J. Garcia-Orellana, E. Garcia-Solsona, L. Martinez-Ribes, and R. Vaquer-Sunyer. 2010. Submarine groundwater discharge to the coastal environment of a Mediterranean island (Majorca, Spain): ecosystem and biogeochemical significance. Ecosystems 13: 629-643.
Beardsley, R.C. and L.K. Rosenfeld. 1983. Introduction to the CODE-1 moored array and large-scale data report. In CODE-1: Moored Array and Large-Scale Data Report, ed. L.K. Rosenfeld, Woods Hole Oceanogr. Inst. Tech. Rep. WHOI-83-23, CODE Tech. Rep. 21, 1216, Woods Hole, Massachusetts.

Blauw, A.N., E. Beninca, R.W.P.M. Laane, N. Greenwood, and J. Huisman. 2012. Dancing with the tides: Fluctuations of coastal phytoplankton orchestrated by different oscillatory models of the tidal cycle. PloS One 7: 1-14.

Boldrin, A., S. Carniel, M. Giani, M. Marini, F. Bernardi-Aubry, A. Campanelli, F. Grilli, and A. Russo. 2009. The effects of bora wind on physical and bio-chemical properties of stratified waters in the northern Adriatic. Journal of Geophysical Research 114: C08S92. doi:10.1029/2008JC004837.

Borum, J., and K. Sand-Jensen. 1996. Is total primary production in shallow coastal marine waters stimulated by nitrogen loading? Oikos 76: 406-410.

Chen, Z., C. Hu, F.E. Muller-Karger, and M.E. Luther. 2010. Short-term variability of suspended sediment and phytoplankton in Tampa Bay, Florida: Observations from a coastal oceanographic tower and ocean color satellites. Estuarine, Coastal and Shelf Science 89: 62-72.

Cloern, J.E., and A. Jassby. 2010. Patterns and scales of phytoplankton variability in estuarine-coastal ecosystems. Estuaries and Coasts 33: $230-241$.

Cloern, J.E. 1991. Tidal stirring and phytoplankton bloom dynamics in an estuary. Journal of Marine Research 49: 203-221.

Dortch, Q., and T.E. Whitledge. 1992. Does nitrogen or silicon limit phytoplankton production in the Mississippi River plume and nearby regions? Continental Shelf Research 12: 1293-1309.

Doswell, C.A. III, C. Ramis, R. Romero, and S. Alonso. 1998. A diagnostic study for three heavy precipitation episodes in the western Mediterranean region. Weather and Forecasting 13: 102-124.

Dyer, K.R. 1997. Estuaries: A physical introduction. Chichester: Wiley and Sons.

Estrela, T., M. Menendez, M. Dimas, C. Marcuello, G. Rees, G. Cole, K. Weber, J. Grath, J. Leonard, N.B. Oveson, J. Feher, and V. Consulkt. 2001. Sustainable water use in Europe. Part 3: Extreme hydrological events: Floods and droughts. Environmental issue report No 21. Copenhagen: EEA.

Eyre, B.D., and A.J.P. Ferguson. 2006. Impact of a flood event on benthic and pelagic coupling in a sub-tropical east Australian Estuary (Brunswick). Estuarine, Coastal and Shelf Science 66: 111-122.

Garcés, E., and J. Camp. 2012. Habitat changes in the Mediterranean Sea and the consequences for harmful algal blooms formation. In Life in the Mediterranean Sea: A look at habitat changes, ed. Noga Stambler, 519-541. New York: Nova Science Publishers Inc.Chapter 19

Garnier, J., A. Sferratore, M. Meybeck, G. Billen, and H. Dürr. 2006. Modelling silica transfer processes in river catchments. In The silicon cycle. Human perturbations and impacts on aquatic systems, ed. V. Ittekkot, D. Unger, C. Humborg, and N. Tac An, 139-162. Washington D.C.: Island Press.Chapter 10

Geyer, W.R. 1997. Influence of wind on dynamics and flushing of shallow estuaries. Estuarine, Coastal and Shelf Science 44: 713-722.

Gillanders, B.M., and M.J. Kingsford. 2002. Impact of changes in flow of freshwater on estuarine and open coastal habitats and the associated organisms. Oceanography and Marine Biology Annual Review 40: 233-309.

Giorgi, F. 2006. Climate change hot-spots. Geophysical Research Letters. 33: L08707.

Giorgi, F., and P. Lionello. 2008. Climate change projections for the Mediterranean region. Global and Planetary Change 63: 90-104.

Gobler, C.J., L.A. Cullison, F. Koch, T.M. Harder, and J.W. Krause. 2005. Influence of freshwater flow, ocean exchange, and seasonal cycles on phytoplankton-nutrient dynamics in a temporarily open estuary. Estuarine, Coastal and Shelf Science 65: 275-288. 
Gonella, J. 1972. A rotary-component method for analysing meteorological and oceanographic vector time series. Deep-Sea Research 19: 833-846.

Grasshoff, K., M. Ehrhardt, and K. Kremling. 1983. Methods of seawater analysis. Weinheim: Verlag-Chemie.

Guadayol, Ò., F. Peters, C. Marrasé, J.M. Gasol, C. Roldán, E. Berdalet, R. Massana, and A. Sabata. 2009. Episodic meteorological and nutrient load events as drivers of coastal ecosystem dynamics: A time series analysis. Marine Ecology Progress Series 381: 139-151.

Guizien, K., F. Charles, F. Lantoine, and J.J. Naudin. 2007. Nearshore dynamics of nutrients and chlorophyll during Mediterranean-type flash-floods. Aquatic Living Resources 20: 3-14.

Hall, N.S., H.W. Paerl, B.L. Peierls, A.C. Whipple, and K.L. Rossignol. 2013. Effects of climatic variability on phytoplankton biomass and community structure in the eutrophic, microtidal, New River Estuary, North Carolina, USA. Estuarine, Coastal and Shelf Science 117: 70-82.

Harding, L.W. Jr. 1994. Long-term trends in the distribution of phytoplankton in Chesapeake Bay: Roles of light, nutrients and streamflow. Marine Ecology Progress Series 104: 267-291.

Hearn, C.J. 1998. Application of the Stommel model to shallow Mediterranean estuaries and their characterization. Journal of Geophysical Research 103: 10391-10404.

Hearn, C.J., and B.J. Robson. 2002. On the effects of wind and tides on the hydrodynamics of a shallow Mediterranean estuary. Continental Shelf Research 22: 2655-2672.

Howarth, R.W. 1988. Nutrient limitation of net primary production in marine ecosystems. Annual Review in Ecology 19: 89-110.

Jordi, A., G. Basterretxea and D.P. Wang. 2009a. Evidence of sediment resuspension by island trapped waves. Geophysical Research Letters 36. doi: L18610

Jordi, A., G. Basterretxea, and S. Anglès. 2009b. Influence of ocean circulation on phytoplankton biomass distribution in the Balearic Sea: Study based on sea-viewing wide field-of-view sensor and altimetry satellite data. Journal of Geophysical Research 114: C11005.

Jordi, A., G. Basterretxea, and D.P. Wang. 2011. Local versus remote wind effects on the coastal circulation of a microtidal bay in the Mediterranean Sea. Journal of Marine Systems 88: 312-322. doi:10.1016/j.jmarsys.2011.05.007.

Largier, J.L., J.T. Hollibaugh, and S.V. Smith. 1997. Seasonally hypersaline estuaries in Mediterranean-climate regions. Estuarine, Coastal and Shelf Science 45: 789-797.

Levin, L.A., D.F. Boesch, A. Covich, C. Dahm, C. Erséus, K.C. Ewel, R.T. Kneib, A. Moldenke, M.A. Palmer, and P. Snelgrove. 2001. The function of marine critical transition zones and the importance of sediment biodiversity. Ecosystems 4: 430-451.

Lichter, M., M. Klein, and D. Zviely. 2011. Dynamic morphology of small south-eastern Mediterranean river mouths: A conceptual model. Earth Surface Processes and Landforms 36: 547-562.

Lipizer, M., C. De Vittor, C. Falconi, C. Comici, F. Tamberlich, and M. Giani. 2012. Effects of intense physical and biological forcing factors on CNP pools in coastal waters (Gulf of Trieste, northern Adriatic Sea). Estuarine, Coastal and Shelf Science 115: 40-50.

Lorenz, E. N. 1956. Empirical orthogonal functions and statistical weather prediction. Sci. Rep. 1, 49 pp., Mass. Inst. of Technol., Cambridge.

Malej, A., P. Mozetič, V. Malačič, and V. Turk. 1997. Response of summer phytoplankton to episodic meteorological events (Gulf of Trieste, Adriatic Sea). PSZNI Marine Ecology 18: 273-288.

Mallin, M.A., M.H. Posey, M.R. McIver, D.C. Parsons, S.H. Ensign, and T.D. Alphin. 2002. Impacts and recovery from multiple hurricanes in a Piedmont-coastal plain river system. Bioscience 52: 999-1010.

Martínez-Soto, M.C., G. Basterretxea, E. Garcés, S. Anglès, A. Jordi, and A. Tovar-Sánchez. 2015. Species-specific variation in the phosphorus nutritional sources by microphytoplankton in a Mediterranean estuary. Frontiers in Marine Science 2: 54. doi:10.3389/fmars.2015.00054.
Mooers, C. 1973. A technique for analysis of pair complex-valued time series. Deep-Sea Research 20: 1129-1141.

Nakane, T., K. Nakaka, H. Bouman, and T. Platt. 2008. Environmental control of short-term variation in the plankton community of inner Tokyo Bay, Japan. Estuarine, Coastal and Shelf Science 78: 796-810.

Nicolau, R., A. Galera-Cunha, and Y. Lucas. 2006. Transfer of nutrients and labile metals from the continent to the sea by a small Mediterranean river. Chemosphere 63: 469-476.

Nielsen, E., and K. Richardson. 1996. Can changes in the fisheries yield in the Kattegat (1950-1992) be linked to changes in primary production? ICES Journal of Marine Science 53: 988-994.

O'Callaghan, J., C. Pattiaratchi, and H. Hamilton. 2007. The response of circulation and salinity in a micro-tidal estuary to sub-tidal oscillations in coastal sea surface. Continental Shelf Research 27: 1947-1965.

Paerl, H.W. 1997. Coastal eutrophication and harmful algal blooms: Importance of atmospheric deposition and groundwater as "new" nitrogen and other nutrient sources. Limnology and Oceanography 42: $1154-1165$.

Palomera, I. 1992. Spawning of anchovy Engraulis encrasicolus in the Northwestern Mediterranean relative to hydrographic features in the region. Marine Ecology Progress Series. 79: 215-223.

Parsons, T.R., Y. Maita, and C.M. Lalli. 1984. A manual of chemical and biological methods for seawater analysis. Oxford: Pergamon Press.

Pinckney, J.L., H.W. Paerl, and M.B. Harrington. 1999. Responses of the phytoplankton community growth rate to nutrient pulses in variable estuarine environments. Journal of Phycology 35: 1455-1463.

Pitcher, G.C., A.J. Boyd, D.A. Horstman, and B.A. Mitchell-Innes. 1998. Subsurface dinoflagellate populations, frontal blooms and the formation of red tide in the southern Benguela upwelling system. Marine Ecology Progress Series 172: 253-264.

Rabalais, N.N., R.E. Turner, R.J. Diaz, and D. Justic. 2009. Global change and eutrophication of coastal waters. ICES Journal of Marine Science 66: 1528-1537.

Ramos, A.M., N. Cortesi, and R.M. Trigo. 2014. Circulation weather types and spatial variability of daily precipitation in the Iberian Peninsula. Frontiers in Earth Science 2: 25. doi:10.3389/feart.2014.00025.

Rodellas, V., J. Garcia-Orellana, P. Masqué, and J.S. Font-Muñoz. 2015. The influence of sediment sources on radium-derived estimates of Submarine Groundwater Discharge. Marine Chemistry 171: 107117.

Romero, E., F. Peters, L. Arin, and J. Guillén. 2014. Decreased seasonality and high variability of coastal plankton dynamics in an urban location of the NW Mediterranean. Journal of Sea Research 88: $130-143$.

Romero, R., J.A. Guijarro, C. Ramis, and S. Alonso. 1998. A 30 year (1964-1993) daily rainfall data base for the Spanish Mediterranean regions: First exploratory study. International Journal of Climatology 18: 541-560.

Rudek, J., H.W. Paerl, M.A. Mallin, and P.W. Bates. 1991. Seasonal and hydrological control of phytoplankton nutrient limitation in the lower Neuse River Estuary, North Carolina. Marine Ecology Progress Series 75: 133-142.

Scavia, D., J.C. Field, D.F. Boesch, R.W. Buddemeier, D.R. Cayan, V. Burkett, M. Fogarty, M. Harwell, R. Howarth, C. Mason, D.J. Reed, T.C. Royer, A.H. Sallenger, and J.G. Titus. 2002. Climate change impacts on U.S. coastal and marine ecosystems. Estuaries 25: $149-164$.

Siokou-Frangou, I., U. Christaki, M.G. Mazzocchi, M. Montresor, M. Ribera d'Alcalà, D. Vaqué, and A. Zingone. 2010. Plankton in the open Mediterranean Sea: A review. Biogeosciences 7: 1543-1586.

Sferratore, A., J. Garnier, G. Billen, D. Conley, and S. Pinault. 2006. Silica diffuse and point sources in the Seine watershed. Environmental Science and Technology 40: 6630-6635.

Smayda, T.J. 1997. Harmful algal blooms: Their ecophysiology and general relevance to phytoplankton blooms in the sea. Limnology and Oceanography 42: 1137-1153. doi:10.4319/1o.1997.42.5 part_2.1137. 
Spatharis, S., G. Tsirtsis, D. Danielidis, T. Do Chi, and D. Mouillot. 2007. Effects of pulsed nutrient inputs on phytoplankton assemblage structure and blooms in an enclosed coastal area. Estuarine, Coastal and Shelf Science 73: 807-815.

Stanley, S.M. 1973. An explanation for Cope's rule. Evolution 27: 1-26.

Thompson, P.A., T.D. O’Brien, H.W. Paerl, B.L. Peierls, P.J. Harrison, and M. Robb. 2015. Precipitation as a driver of phytoplankton ecology in coastal waters: A climatic perspective. Estuarine, Coastal and Shelf Science 162: 119-129.

Tomasko, D.A., C. Anastasiou, and C. Kovach. 2006. Dissolved oxygen dynamics in Charlotte Harbor and its contributing watershed, in response to Hurricanes Charley, Frances, and Jeanne impacts and recovery. Estuaries and Coasts 29: 932-938.

Torrence, C., and G.P. Compo. 1998. A practical guide to wavelet analysis. Bulletin of the American Meteorological Society 79: 61-78.
Tzoraki, O., and N.P. Nikolaidis. 2007. A generalized framework for modeling the hydrologic and biogeochemical response of a Mediterranean temporary river basin. Journal of Hydrology 346: 112-121.

Ubertini, M., S. Lefebvre, A. Gangnery, K. Grangere, R. Le Gendre, and F. Orvain. 2012. Spatial variability of benthic-pelagic coupling in an estuary ecosystem: Consequences for microphytobenthos resuspension phenomenon. PloS One 7: e44155. doi:10.1371/journal.pone.0044155.

Valiela, I., P. Peckol, C. D’Avanzo, J. Kremer, D. Hersh, K. Foreman, K. Lajtha, B. Seely, W.R. Geyer, T. Isaji, and R. Crawford. 1998. Ecological effects of major storms on coastal watersheds and coastal waters: Hurricane Bob on Cape Cod. Journal of Coastal Research 14: $218-238$.

Yeager, C.L.J., L.W. Harding, and M.E. Mallonee. 2005. Phytoplankton production, biomass and community structure following a summer nutrient pulse in Chesapeake Bay. Aquatic Ecology 39: 135-149. 